\title{
歩行形態を利用した歩行者の移動経路の抽出
}

\author{
三宅 康 雄 ${ }^{\dagger}$, 正会員 堤 喜代 司 $^{\dagger}$, \\ 正会員 平 井 宏 ${ }^{\dagger}$, 正会員 弓場 芳 治 ${ }^{\dagger \dagger}$
}

\section{Extraction of Routes of Walkers Utilizing Conditions of Walking}

\author{
Yasuo Miyake ${ }^{\dagger}$, Kiyoshi Tsutsumi ${ }^{\dagger}$, Hiroshi Hirai $^{\dagger}$ and Yoshiharu Yuba ${ }^{\dagger \dagger}$
}

\begin{abstract}
A method of extracting routes of walkers based on investigation of speed and direction change over a short period is proposed. Images in time series are taken alternately with two values of intervals. The position of a walker after a longer interval is determined by using a vector of movement obtained from images over a shorter interval. Good accuracy is compatible with short computation time. By using a trapezoidal mask, a portion of one person is extracted from a figure in which some walkers are connected. This mask is determined from the parallax of two cameras. Our method does not require identification of a person and is expected to decrease computation time. Routes of walkers were almost always extracted in our experiment.
\end{abstract}

\section{1. まえがき}

近年，多くの分野で，歩行者の流れを把握すること が要請されている．移動方向が限定されるゲート等で は，比較的簡単なセンサで通行量を計測できる。しか し，広場など移動方向が限定されない場合にはセンサ では限界がある。カメラによる画像情報を用いること が有効であると考えられ，画像処理に基づく研究が行 われている112).

画像を用いて歩行者の移動経路を求めることは，現 在の時刻の画像中の人物を前の時刻あるいは次の時刻 の画像中のその人物と対応づけることにほかならな
い.このためには，画像中の歩行人物の領域を抽出す る必要がある. 移動物体や人物を背景から切り出す方 法として, 時系列の差分 ${ }^{3) 4}$, 逐次更新される背景画 像との差分 ${ }^{5)}$, 背景の輝度や特徵量との比較(6) 8)など が提案されている.また, 歩行者の移動経路を求める にあたっては，時系列の差分 ${ }^{1)}$ 逐次更新される背景 の特徵量との比較 ${ }^{2}$ が行われている. 人物が 1 人分ご とに分離しているとは限らないので, 人物部分を背景 から切り出したあと, 1 人分の人物部分を抽出しなけ ればならない。このために，個々の人物の特徵を抽出 することが行われている213).

実用的なシステムを目ざす場合には，計算量をでき

キーワード : 歩行者の流れの計測, 屋外情景画像, 2 眼視, 動画像処理, 不等間隔サンプリング

1993 年 9 月 8 日, 1993 年電子情報通信学会秋季大会で発表

1994 年 3 月 28 日受付, 1994 年 10 月 14 日再受付

$\dagger$ 京都工芸繊維大学 工芸学部電子情報工学科 (テ 606 京都市左京区松ケ崎御所海道町, TEL 075-724-7419)

†† 岡山県立大学 情報工学部情報システム工学科 (テ 719-11 総社市䆶木 111, TEL 08669-4-2140)

$\dagger$ Faculty of Engineering and Design, Kyoto Institute of Technology (Goshokaido-cho, Matsugasaki, Sakyo-ku, Kyoto 606, Japan)

$\dagger \dagger$ Faculty of Information Engineering, Okayama Prefectural University (111, Kuboki, Soja-shi, Okayama 719-11, Japan) 
るだけ少なくする必要があり, 個々人や背景の特徵抽 出を行わずにすめば計算量の減少が期待できる。

本論文では，歩行者個々人の特徴抽出を行わずに， 1 人分の人物部分を抽出し, その移動経路を求めるこ とができる手法を提案する。筆者らは，先に屋外の地 平面に生じた影を 2 台のカメラによる画像を用いて消 去する一方法を提案した ${ }^{9)}$.この方法によれば，人物 部を特別な形状として取り出すことができる。この形 状を用いる探索によって, 個々の人物の特徴を抽出し なくても人物 1 人分を抽出できると考えられ, 計算量 の減少が期待される.

次に, 現在の時刻の画像中の人物と前後の時刻の画 像中の人物との対応づけにあたっても, 個々の人物の 特徵を抽出せずにすむ方法が望ましい，時空間画像か ら運動軌跡を求めることが提案されている ${ }^{10)}$. この方 法では, 1 人の人物の領域が途切れないように, 現在 の時刻の画像中の人物が次の時刻の画像中のその人物 と最も近くにあり，ほとんど重なる程度に充分短い時 間間隔で画像デー夕を取り込む必要がある。これと同 様の考えに基づけば，個々の人物の特徴抽出を行わず に移動経路が求められると考元られる。すなわち， あ る歩行者は, ごく短い時間のあとでは最も近くにいる 人物に他ならないと考えることにより，その移動経路 を求めることができる。しかし，このときも時間間隔 が短くなると扱うべきデー夕がぼう大となり, 計算量 が多くなる。したがって, 画像デー夕の時間間隔をい くらにすればよいかについての検討が必要になる。

本論文では, 歩行形態を考慮した 2 種類の時間間隔 での画像デー夕を用いて, 前の時刻あるいは次の時刻 の画像中の人物部分との対応づけを行う。すなわち, 誤差の少ない精度を重視した短い時間間隔と, 計算処 理を簡単化する比較的長い時間間隔とを交互に用いる ことによって, 精度と処理速度の両方を考慮した時間 間隔が設定できると考えられる，以下では，まず， 2 章で本方法の概要を明らかにし， 3 章において人物部 分の抽出, 4 章では移動経路の抽出の詳細を述べ, 5 章では大学構内において行った実験結果を使用したパ ラメータとともに示す。

\section{2. 移動経路抽出の原理と方法}

画像中での人物 1 人分の領域を正しく抽出できるな らば,ごく短い時間間隔ごとに画像を取り込んで最も 近くの人物の位置を結んでいくことにより，移動経路 が求められる.

混雑していない状況での歩行者の調査から, 通常の 場合, 人の歩く速度は $1.1 \mathrm{~m} / \mathrm{s}$ 程度であること, 歩
行者と歩行者の間隔は約 $90 \mathrm{~cm}$ 以上離れていること, また, $2 / 5 \mathrm{~s}$ 程度より短い時間内では, 歩行者の移動 速度と進行方向にあまり変化がないことなどがわかっ た．これらの結果は，当然のことながら，どのような 歩行者にもあてはまるものではないが，かなりの場合 に成り立つものと考えられる。そこで, 画像取り込み の時間間隔を $2 / 5 \mathrm{~s}$ あるいはそれよりも短い時間とす る。この時間間隔(これを短サンプリング間隔と呼ぶ) で得られた距離と移動方向の情報（移動べクトルと呼 ぶ）を用いれば，他の歩行者との対応づけに誤りを犯 さないと考えられる．この時間間隔での処理は正確で あるが, 計算量は多い.

そこで必要な画像デー夕を少なくするために, 図 1 に示すように，短サンプリング間隔で得た画像の次の 画像は, より長い時間間隔で取込むものとする。この 時間間隔(これを基本サンプリング間隔と呼ぶ) は, 歩 行速度 $1.1 \mathrm{~m} / \mathrm{s}$ 程度の場合に約 $90 \mathrm{~cm}$ の移動に要す る時間すなわち約 $0.8 \mathrm{~s}$ 程度以上に設定してよいと考 えられる. 当然, 計算量は減少するが, 探索を誤る可 能性も増大する. 他の歩行者との誤りが起こらないと 考えられるときは，もっと大きくとることも可能であ る. 本論文では比較的無難な值として $4 / 5 \mathrm{~s}$ を設定し た。ただし，短サンプリング間隔を $2 / 5 \mathrm{~s}$ 程度よりか なり短くすると, 歩行姿勢の影響がでてきて移動べク トルの抽出誤差が大きくなる恐れがあり，したがって 短サンプリング間隔を $2 / 5 \mathrm{~s}$ 程度よりかなり短くする と，それに応じて基本サンプリング間隔も約 $0.8 \mathrm{~s}$ よ り短くしなければならない場合もあると思われる。

本論文では, 短サンプリング間隔による移動ベクト ルを用いて移動経路の推定を行うという考えに基づ き, 長い方の時間間隔を基本間隔と考えた。 以上が 2 つの時間間隔を用いて人物追跡を行う原理である.

人物抽出を含めた本方法の処理の流れを図 2 に示 す. 画像中で人物の部分がある程度大きく写り, 近く の人物とあまり重ならないようにするため, 図 3 亿示 すように, 2 台のカメラを撮影範囲の斜め上方に配置 する.

人物部分の抽出に関しては，まず，得られた 2 枚の 画像の地平面が一致する画像変換を行ったのち, これ

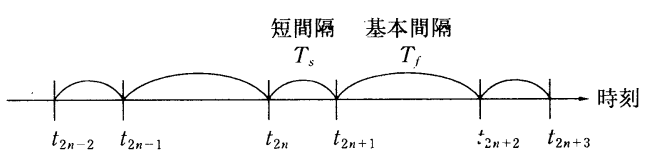

図 1 サンプリング間隔の設定 Sampling intervals.

テレビジョン学会誌 Vol. 49, No. 1 


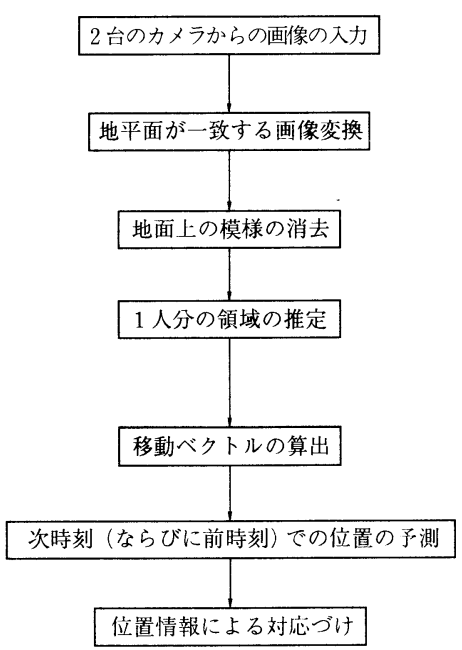

図 2 処理の流れ

Flow chart of this method.

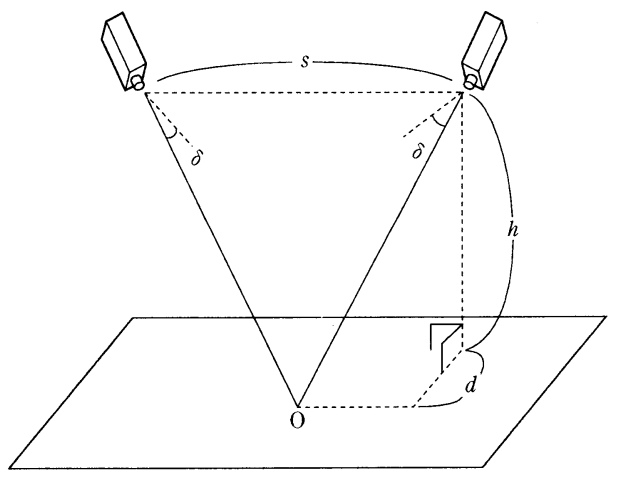

図 3 カメラの配置

Location of two cameras.

らの画像の差の絶対値をとり, 人物部分を取り出す. 通常, 歩行者は道路面に立って歩行することから, 人 物部分は $\mathrm{V}$ 字形あるいは台形に近い形状となって得 られる.複数の人物が画像中でつながって大きい 1 つ の領域を作っていても，それから V 字形あるいは台 形に近い形状の部分を取り出せば，それが 1 人分の人 物部分であると考えられる。そこで，台形のマスクを 2 人以上の人物部分で移動して，1 1 人分の人物部分を 抽出する.

前後の時刻での人物部分との対応づけに関しては, まず, 短サンプリング間隔での画像(時刻 $t_{2 n}, t_{2 n+1}$ ) から距離と移動の方向を示す移動べクトルを求める. 次に, この移動ベクトルを用いて, 次の時刻 $t_{2 n+2}$ で の位置を予測し，これに基づいて対応づけを行う。こ の移動ベクトルを用いれば, 前の時刻で対応がとれて いない場合にも，時間軸を逆にして，同様のことを行

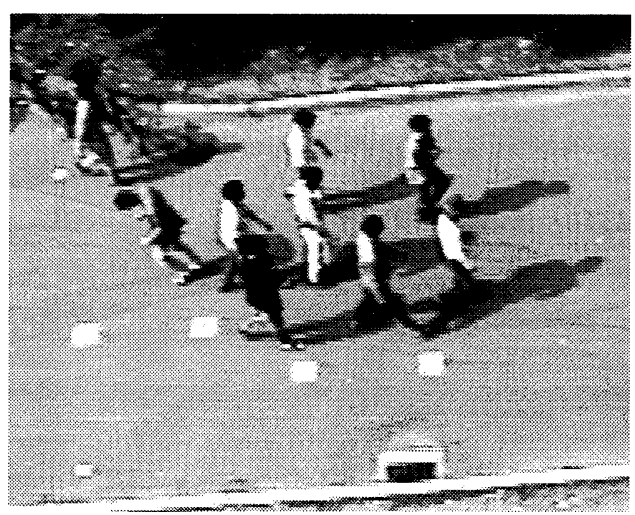

(a) 右力メラ

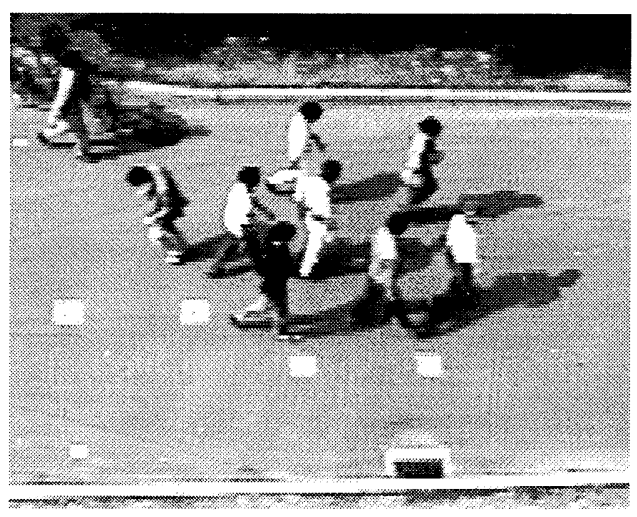

(b) 左カメラ

図４2台のカメラによる画像 Original pictures taken by two cameras. (a) Right camera, (b ) left camera.

うことによって対応づけが可能となる場合がある。

\section{3. 人物部分の抽出}

\section{1 画像変換と視差画像}

図 3 に示したように，2台のカメラを撮影範囲の斜 め上方に配置し, それぞれのカメラの光軸は地平面の 1 点で交わるように設定する。座標系として, カメラ の光軸が交わる点を原点とし, 地平面上に $X$ 軸と $Y$ 軸をとり, 高さ方向に $Z$ 軸をとる.また, カメラ画 像の座標を $(H, V)$ と定める. 右カメラおよび左カメ ラで撮影した画像の一例を図 4(a), (b) に示す。こ の図では, 横 360 画素×縦 290 画素の範囲が表示され ている。どちらか一方のカメラ（例えば左カメラ）の 画像を変換するものとし, 左カメラ画像での地平面上 $(Z=0)$ の模様を他方の右カメラ画像での地平面上の 模样に一致させる変換を行う. 図 4 (b) 変換した画 像を図 5 に示す。図 5 で左端の黒の三角形は画像デー 


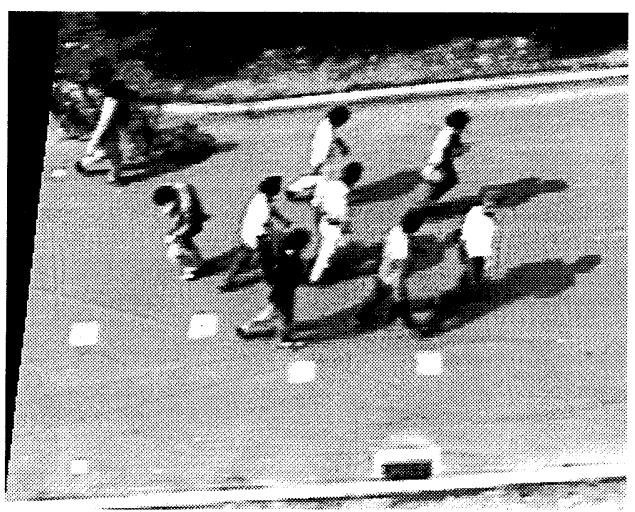

図 5 図 4 (b) の変換画像

Transformed image from Fig. 4( b )

夕がない部分であり,この部分については以降の処理 を行わない. 左カメラ画像の座標 $\left(H_{L}, V_{L}\right)$ の画素を 新しい座標 $\left(H_{L}^{\prime}, V_{L}^{\prime}\right)$ に写像するわけで, これに必要 な式を付録に示す．この画像変換を行うと, $Z=0$ の 面上の点は左右画像（右カメラ画像と変換された左力 メラ画像）で一致するが， $Z=0$ の面上にない点は一 致しない。したがって, 物体の高さが高いほど, 左右 画像で離れた位置に写像されることになる。

右カメラ画像（図 $4(\mathrm{a})$ ) と変換された左カメラ画 像（図 5 ）の同一座標の画素間で, 輝度の差の絶対值 をとる。 2 枚の画像において生じた視差の画像が 1 枚 の画像にまとめた形で現れる，輝度の差をとるため, 同一輝度の部分が消え，また，地面付近の足の部分も 消えてしまう。

屋外の環境において歩行者の影が生じなければ, 道 路や人物部分の輝度が変化しても, 時系列差分や背景 画像・背景特徴量の更新を行えば人物部分を正しく抽 出できると思われる。しかし，歩行者の影が生じる と, 影は歩行者と一体となって移動するので, 人物部 分の抽出に誤りが生じる ${ }^{1)}$. 本論文では, 幾何学的な 変換を用いるので, どのような場合もほぼ完全に影を 消去でき, 人物部分を正しく抽出できると考えられ る.人物がほぼ平坦な道路面を歩行する場合を想定し ており，道路面が階段であったり，わん曲している と, 背景を消去するための画像変換や人物抽出のため のマスクを別のものにしなければならない。また，鏡 面反射成分があってもカメラの輻輳角をそれほど大き くしなければ，さしつかえない場合が多いと思われる が，水たまりなどでの八イライトが左右画像で異な り，完全に消去されないことも起こり得る．現実の状 況は多種多様であるので，すべての場合に適用できる
とは限らないが，たいていの場合に適用可能であると 考えている。

以上の処理によって，歩行者はV 字形あるいは台 形に近い形状になる。このあと, 判別分析法で 2 值化 したのち，孤立点などの小さい領域を除去し，囲みが できたところは穴埋め処理を行う.

\section{2 人物部分の外接長方形の抽出}

視差を表す画像では， 1 人の人物が複数の塊に分か れることがある。そこで，近接した複数の塊をまとめ る。

まず， $P_{\min }$ 画素以上の塊を人物部分の主要な部分 とみなし，この画素の塊に対して，その外接長方形を 考える ${ }^{11)}$.これに, 近接した塊のうち $P_{\min }$ 画素末満 のものを順次結合する.

ここで，この外接長方形が何人の人物を表している かは，外接長方形に含まれる画素の個数と各辺の長さ により判定する．外接長方形に含まれる画素の個数が $P_{\max }$ 画素以下であり, 各辺が横 $h_{\text {max }}$ 画素以下でかつ 縦 $v_{\max }$ 画素以下であるものを 1 人の人物部分とし, これを越える場合は 2 人以上とする.

最初の外接長方形が 1 人分に相当する場合，新たに 得られた外接長方形に含まれる画素の個数あるいは各 辺の長さが 1 人分の数値を越えたら，画素の塊の結合 を終える。これを 1 人の人物部分とする.

最初の外接長方形が 2 人分以上に相当する場合, 新 たに得られた外接長方形に含まれる画素の個数あるい は各辺の長さが元の值の $k$ 倍を越えたら, 塊の結合 を終える。

$P_{\text {min }}$ 画素未満の塊のうちで残ったものに, 近接し た塊を順次結合する．結合した画素数の総和が $P_{\text {min }}$ 画素以上になれば，これを 1 人の人物部分とする.

\subsection{1 人分の人物部分の抽出}

2 人以上の人物部分から， 1 人分の人物部分を抽出 する. 台形マスクは, 長さ $170 \mathrm{~cm}$ の棒が撮影範囲の 中央で地面に垂直に立っている場合に，右画像での棒 と左変換画像での棒の両方が入る大きさとし,さら に，人物の頭の幅と足の幅执よび消える足の位置を考 慮したものである.図 6 にその形状を示す.

カメラの設定条件から，外接長方形の上辺および底 辺に人物がいるものとみなせる。そこで，まず上辺と 底辺のそれぞれに沿って，台形のマスクを外接長方形 内で移動して人物部分を探す。上辺側および底辺側の それぞれについて，台形マスク中の画素数を最大にす る部分を 1 人分の人物部分とする。この部分の画素に マークを付ける. 次に, 外接長方形の左上からラス夕 一走查的に台形マスクを移動する。台形マスク内で, 


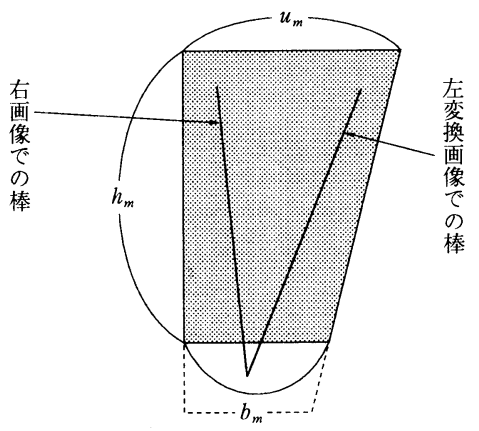

図 6 台形マスク

Trapezoidal mask.

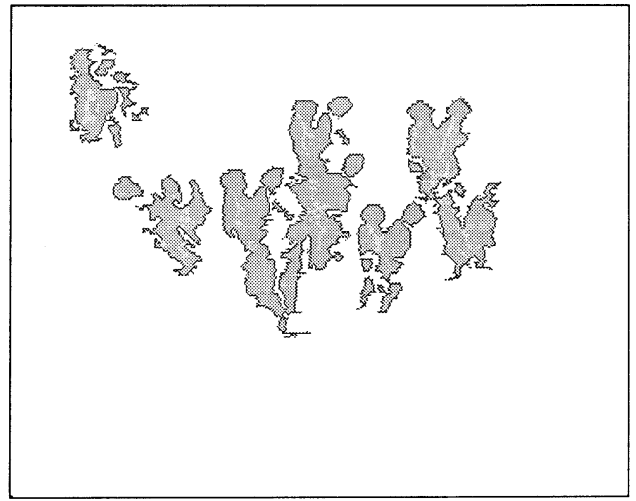

図 7 抽出された人物部分

Pixels expressing walkers.

図 81 人分の人物部分の抽出

Extracted nine portions of walkers.

マークされていない画素数が最大で, さらに, マーク の有無にかかわらず画素数が最大になる部分を 1 人分 の人物部分とする. 台形マスク内でマークされていな い最大画素数が $m$ 画素以下になるまで, この処理を
繰り返す. 図 7 に対して 1 人分の人物部分を抽出した 結果を図 8 に示す。

なお，各パラメータの值は，カメラの設定や画像入 力時の画素分解能によって決めるべきものであり, 実 験での值を 5 章に記す。

\section{4. 人物部分の移動経路の抽出}

2 つのサンプリング間隔における人物部分の対応づ けについて述べる。人物部分として抽出された 1 つの 外接長方形ごとに移動経路を抽出する。また， 2 人以 上の外接長方形から 1 人の人物部分が分離した場合 は，2 人以上の人物部分のうちで，どの部分が分かれ たかを判定する。これは， 2 人以上の人物部分につい ては，1つのグループとして，移動経路に関しては同 一の経路をとると考え，そのうちで異なる方向に移動 した歩行者だけを分離するものである。

\section{1 短サンプリング間隔での対応づけ}

短い時間では歩行者は元の位置からそれほど移動し ないと考えられるので, 次の時刻 $t_{2 n+1}$ での外接長方 形 (あるいは台形) のうちで, 時刻 $t_{2 n}$ での外接長方形 （あるいは台形）に最も近いものを対応づける。ただ し，外接長方形あるいは台形間の距離は，その中心点 について求めるものとする. 台形の中心点としては, その台形に外接する長方形の中心点を用いる.

1 人の人物部分については， 2 人以上の人物部分の 外接長方形内の台形も対応づけの対象とする。また, 2 人以上の人物部分のうちの台形については, 前時刻 で対応づけされたものについてのみ移動先を求めるも のとする. 対応づけされなかった台形はそのままにし ておき, 2 人以上の人物部分の外接長方形として対応 づけを行う。

得られた結果は，移動距離と方向を持つ移動べクト ルとして扱う.

\section{2 基本サンプリング間隔での対応づけ}

基本サンプリング間隔を $T_{f}$ ，短サンプリング間隔 を $T_{s}$ として, 図9 に示すように, 時刻 $t_{2 n+1}$ での位 置（外接長方形あるいは台形の中心） $P_{2 n+1}$ から移動心゙ クトルの $T_{f} / T_{s}$ 倍だけシフトした点を求める。この 点を次時刻 $t_{2 n+2}$ での位置の予測点とし, この予測点 と次時刻 $t_{2 n+2}$ の外接長方形 (あるいは台形) の関係に より対応づけを行う。

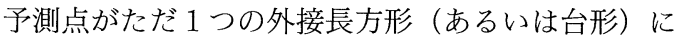
含まれる場合，その外接長方形（あるいは台形）を選 ぶ. 予測点が 2 つ以上の外接長方形（あるいは台形） に含まれる場合，移動べクトルのうちで方向が最も近 い外接長方形（あるいは台形）を選ぶ．予測点がどの 


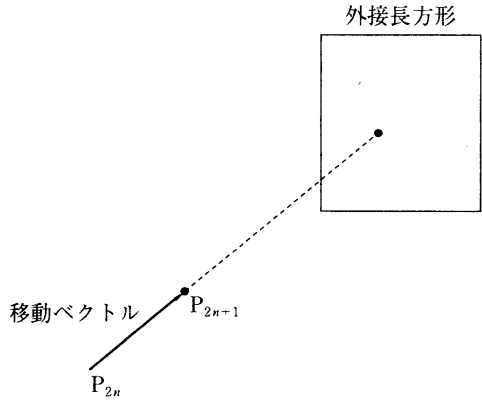

図 9 時刻 $t_{2 n+2}$ での位置の予測

Predicted position of a walker at $t_{2 n+2}$.

外接長方形にも含まれない場合，その点に近接した外 接長方形のうちで最も近いものを選ぶ.

予測位置は点であるが, 人物部分の大きさを表す外 接長方形あるいは台形を対応づけに用いているため, 移動ベクトルのブレに対処していることになる。

\section{3 前の時刻での人物部分との対応づけ}

歩行者が急に方向を変えた場合や， 2 人以上の人物 部分から 1 人の人物部分が分かれた場合は，対応づけ ができず移動経路が途切れることがある. 途切れた経 路を回復するため, 画像の端以外で人物部分の対応づ けが新たに発生した場合, 以下に示すように, 前の時 刻の人物部分との対応づけを行う.

短サンプリング間隔での対応づけを終えたあとで, それ以前での対応づけがないものについては, 時間軸 を逆にして対応づけを求める. 逆向きの移動ベクトル を用いて, 前の時刻での人物部分と対応づけを行う. 2 人以上の人物部分から 1 人の人物部分が分離した場 合も同様の処理を行う. 前時刻での人物部分との対応 づけが完了するまで，この処理を繰り返す。

1 人分の人物部分については, 2 人以上の人物部分 中の台形も対応づけの対象とするので, 2 人の人物が 出会ったのち分かれる場合も個々の人物の移動経路を 求めることができる。ただし，今回の実験では生じな かったが, 短サンプリング間隔内での方向変化が大き ければ, 移動経路を詋って抽出することもあると考え られる。

\section{5. 実 験，結 果}

2 台のカメラの配置は, 図 2 に示すように, それぞ れのカメラの光軸が地面上の 1 点 $\mathrm{O}$ で交わるものと し, 地面 (道路面) からの高さ $h$ を $13 \mathrm{~m}$, 俯角 $\delta$ を $52^{\circ}$, 両カメラの距離 $s$ を $4 \mathrm{~m}$, 距離 $d$ を $10 \mathrm{~m}$ とし た. 大学構内の道路で, 5 人程度の歩行者が方向を変 えながら接近したり遠ざかったりする場合を 3 シーン

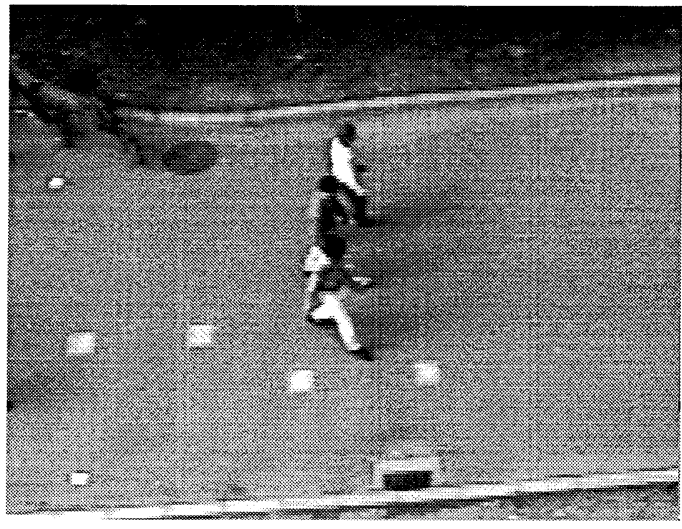

(a) 時刻 $t_{a}$

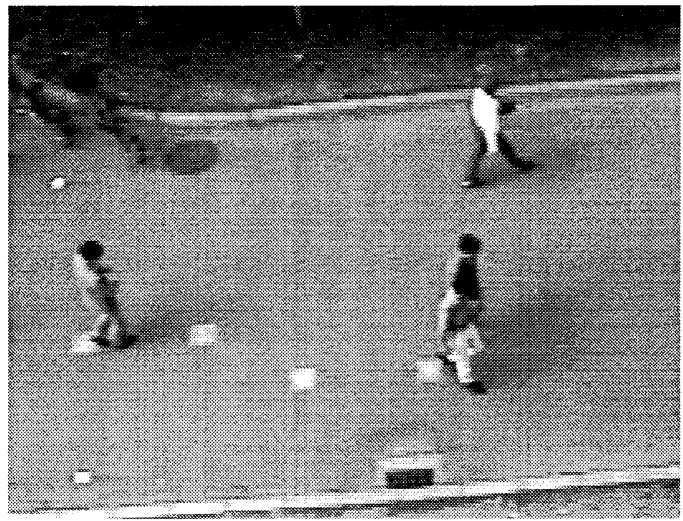

(b) 時刻 $t_{b}$

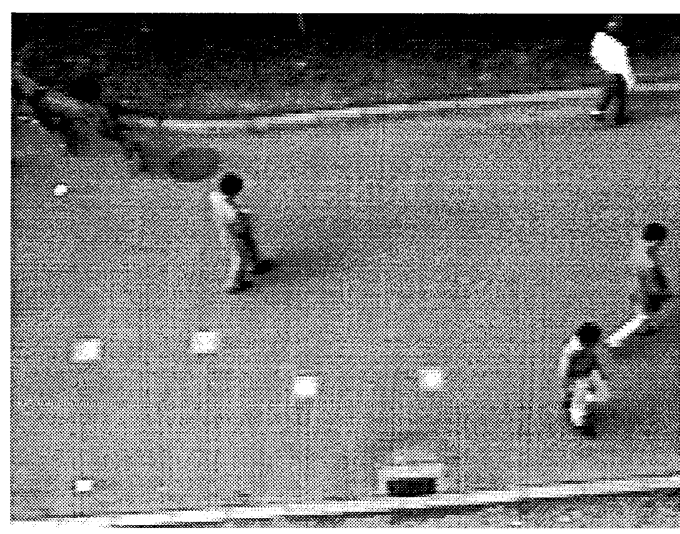

(c) 時刻 $t_{c}$

図 10 時系列 $\left(t_{a}<t_{b}<t_{c}\right)$ の右カメラ画像 Original picture of right camera in time series $\left(t_{a}<t_{b}<t_{c}\right)$. (a) time $t_{a}$, (b) time $t_{b}$, (c) time $t_{c}$.

撮影した。 3 シーンの各々について，時間にして 3.6 $\mathrm{s}$ 間の左右各々 7 枚からなる, 6 組の時系列画像（計 18 例）を得た。サンプリングにあたっては, 短サンプ リング間隔を $2 / 5 \mathrm{~s}$ ，基本サンプリング間隔を $4 / 5 \mathrm{~s}$ 


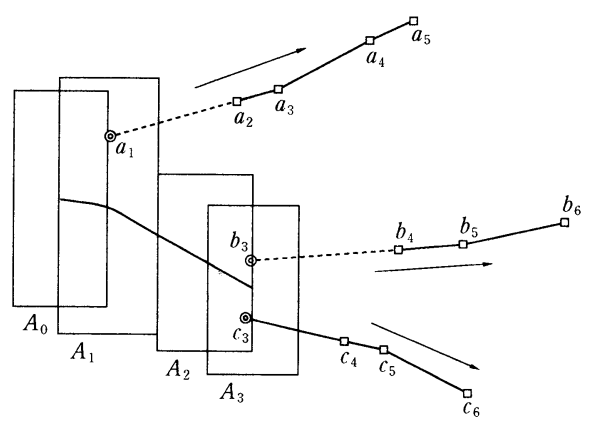

図 11 図 10 の場合の移動経路

Extracted routes of walkers in the case of Fig. 10.

とした。なお，基本サンプリング間隔での対応づけに おいて, 予測点がどの外接長方形にも含まれない場 合, 50 画素以内の距離にある外接長方形を対応づけ の対象とした。

カメラにはSONY $8 \mathrm{~mm}$ ビデオカメラ CCDV 800 , 画像処理装置にはPIAS LA-555, 処理用コ ンピュータには NEC PC-9801 RX を使用した。画 像は縦 $512 \times$ 横 512 画素, 白黒 256 階調で表される。 カメラの焦点距離は概算で左右とも 890 画素と求めら れた。これによって, 実験の設定では 1 画素は道路面 での約 $2 \mathrm{~cm}$ に相当する. 処理時間のほとんどは人物 部分の抽出, とりわけ台形マスクの走査に費やされ る. 台形マスクの走查を何回行うかによって処理時間 が異なるが，実験において，処理の 1 回分すなわち $t_{2 n}, t_{2 n+1}, t_{2 n+2}$ での画像から人物部分とその経路を抽 出するのに要する時間はほとんどの場合 $2 \mathrm{~min}$ 以内で あった．実時間処理を仮定すると，コンピュー夕の計 算速度をこのシステムより 100 倍程度早くすることが 要求される.

2 人以上の人物部分が時間の経過につれて分離する 場合の一例を図10, 図11 に示す。図 10 の (a), (b)，（c）は時刻の経過順の画像である. 図 11 が移 動経路であり，矢印が歩行者の移動方向を示す．図に おいて，2 人以上の人物部分は外接長方形で表し， 1 人の人物部分は中心点を丸印で表している。ただし二 重丸は， 2 人以上の人物部分から 1 人の人物部分が分 離した場合の 1 人分を示す．人物部分が分離すると別 の文字で表している. 添字はサンプリング時刻を表 す．点線によって結ばれている対応は，時間軸を逆に して, 前時刻との対応づけを行ったことを示す。

2 人以上の人物部分 (長方形 $A_{0}$ ) が移動するが，サ ンプリング時刻 $t_{2}$ で 1 人の人物部分 $a_{2}$ と 2 人以上の 人物部分（長方形 $A_{2}$ ）に分かれている. 分離した 1 人

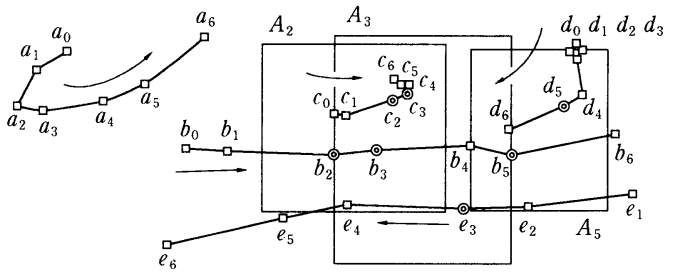

図 12 他の移動経路の抽出例 Another example of extracted routes of walkers.

の人物部分 $\left(a_{2}\right)$ についは, はじめ対応づけが得られ なかったが, 次の短サンプリング間隔で $a_{2} \longrightarrow a_{3}$ の対 応づけが得られた。そこで，時間軸を逆向きにした 4.3 節の処理により, $a_{1} \rightarrow a_{2}$ の対応づけが得られた. 図 11 では，この対応づけが破線で表されている。同 様の処理で, $b_{3} \longrightarrow b_{4}$ の対応づけが得られた。また， $c_{3} \rightarrow c_{4}$ の対応づけは時刻 $t_{4}$ で得られるが, 1 人の人 物部分となったので, $c_{4} \longrightarrow c_{5}$ の対応づけが得られたあ とで 4.3 節の処理が行われた。なお, 図 11 では, 経 路の線を見やすくするため, 図 $10(\mathrm{~b})$ で左から現れ て図 $10(\mathrm{c})$ で中央へ進む歩行者の経路を省略してい る.

2 人以上の人物部分が途中で生じる場合の一例を図 12 に示す。この場合の歩行者は 5 人である. 時刻 $t_{2}$ で $b$ と $c$ が 1 つの人物部分 (長方形 $A_{2}$ )を作り,さら に，時刻 $t_{3}$ で $e$ が合体する (長方形 $A_{3}$ ) . この場合の 対応づけは，1 人分の人物部分を表す台形との間で行 われ，その台形の中心点が二重丸で表されている．時 刻 $t_{4}$ では, $b, c, e$ が各々分離する。このあと, 時刻 $t_{5}$ で $b$ と $d$ が合体し (長方形 $A_{5}$ ), 時刻 $t_{6}$ で $b$ と $d$ が分離する. $t_{4} \sim t_{6}$ の $c$ や $t_{0} \sim t_{3}$ の $d$ はほとんど静止 している.

対象画像において 1 人分の人物部分はすべて正しく 抽出できた． 3 シーン 18 例のうち 16 例で，人物部分 の移動経路を正しく抽出できた．2 例では， 2 人の人 物部分が 1 人ずつに分離したとき， 4.3 節の処理にお いて同一の 1 人分の人物部分に対応づけを行う誤りを 生じた.この 2 例は図 10 , 図 11 と同じシーンの場合 で,一例を図 13 に示す. $b_{3} \rightarrow b_{4}$ と $c_{3} \rightarrow c_{4}$ のいずれ も, 長方形 $A_{3}$ 中の同じ人物部分 ( 1 人分) に対応づけ が行われている。なお，この場合に限れば，移動べク トルは画像中の人物部分の位置から求めているが，地 平面での位置から求めれば，上記の誤りをなくすこと ができることがわかった。したがって，この誤りは歩 行の際の姿勢の変化で人物部分の形状が変化し, 進行 方向の抽出に誤差が生じたためと考えられる。 


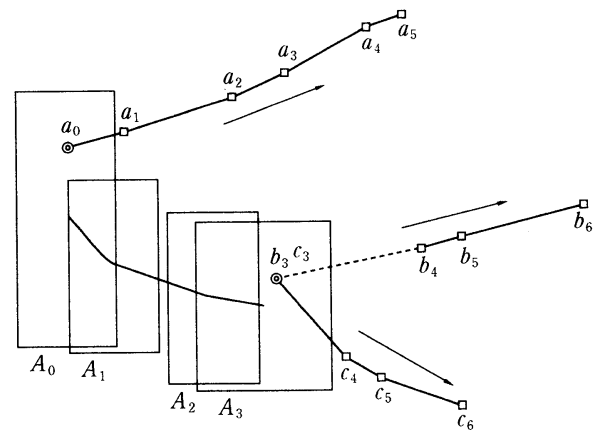

図 13 移動経路抽出の失敗例

A false route of a walker.

表 1 歩行者の人数の推定結果

Estimation of numbers of walkers.

\begin{tabular}{|c|c|c|c|c|c|c|c|c|c|}
\hline & \multicolumn{9}{|c|}{ 外接長方形中の実際の人数 } \\
\hline \multirow{9}{*}{$\begin{array}{l}\text { 外 } \\
\text { 接 } \\
\text { 咅 } \\
\text { 形 } \\
\text { 中 } \\
\text { 稚 } \\
\text { 定 } \\
\text { 数 }\end{array}$} & & 1 & 2 & 3 & 4 & 5 & 6 & 7 & 8 \\
\hline & 1 & 55 & 4 & & & & & & \\
\hline & 2 & & 24 & 2 & 1 & & & & \\
\hline & 3 & & & 7 & 3 & 1 & & & \\
\hline & 4 & & & & 5 & 4 & & & \\
\hline & 5 & & & & & 3 & 1 & & \\
\hline & 6 & & & & & & & & \\
\hline & 7 & & & & & & & & \\
\hline & 8 & & & & & & & & 1 \\
\hline
\end{tabular}

なお，人物部分の抽出にあたって, 結合する画素の 塊は, 20 画素以内の距離のものを対象とした. 各パ ラメータの值は, $P_{\min }=1000, P_{\max }=1500, h_{\max }=$ $75, v_{\max }=75$ とし ${ }^{9)}$, また $k=1.2, m=300$ とし た，台形マスクは，人物の頭の幅 $(15 \mathrm{~cm})$ と足の幅 $(25 \mathrm{~cm})$ および消える足の位置（地上 $20 \mathrm{~cm}$ まで）を 考慮して $, u_{m}=45, b_{m}=30, h_{m}=60$ とした

複数の歩行者が画像中で縦に並び重なり合う度合が 大きいと，1人分の人物部分を抽出する際に誤ること がある. 歩行者が 10 人程度で, 複数の人物が画像中 でつながることが多い場合の画像 25 例について, 歩 行者の人数を求めた結果を表 1 に示す. 人物どうしが 完全に同一線上にのらず少しでも横にずれていれば， 1 人分の人物部分を正しく抽出できることがわかっ た. $85 \%$ の外接長方形について，それに含まれる人物 の数を正しく求めることができた. 全人数に対する正 解率は $92 \%$ あ゙り， 2 人以上の人物部分の合計人数 に対する正解率は $90 \%$ である．誤りが生じた場合に おいては, 本論文での人物抽出法で予想されるように
人数を少なくカウントしたが，その数はほとんどの場 合 1 人であった.

また，人物の実際の位置についても検討した。その 結果, 歩行者の位置を画像から求めたものと実画像か ら求めた真值*との差は平均で $20 \mathrm{~cm}$, 最大で $35 \mathrm{~cm}$ であった．ただし, 歩行者の位置は，1人の人物部分 では外接長方形の底辺の左から $1 / 3$ の距離の点とし, 2 人以上の人物部分では台形の底辺の中点として, 座 標変換により地平面での值を算出した。

\section{6. むす び}

短時間での速度や方向変化などの歩行者の一般的特 性に着目して, 歩行者の移動経路を求める一手法を提 案した。ある時間間隔と, それよりも短い時間間隔の 2 種類のサンプリング間隔により, 比較的少ない画像 で, 前後の時刻の人物部分との対応づけを行う. 本手 法では, 歩行者個々人の特徴量を用いずに, 人物部分 とその移動経路の抽出を行うので, 計算量が少ない. 大学構内での実験結果により, 本手法の有効性を確認 した.

本手法は単純な処理からなるものではあるが，比較 的良い結果が得られたと考えている．今後，歩行者が 多く人物部分の重なりが多いシーンについて実験を行 い, 歩行の形態をより一層反映した移動経路抽出法を 開発しなければならない。また，台形マスクの走査を より効率的に行い，1人分の人物部分の抽出に要する 時間を短縮することが望ましい。そして，サンプリン グ間隔の比率の考察を含め, リアルタイム処理を目指 したい.

\section{〔参 考 文 献〕}

1）竹内啓五, 長田耕治：“画像を利用した群衆流動解析法に関 する研究”, 信学技報, IE90-60（1990）

2）安居院猛, 長尾智晴, 斉藤智明, 中鴆正之: “ブロック特徵を 用いた歩行人物の抽出と追跡”，テレビ誌， $\mathbf{4 5}, 10, \mathrm{pp} .1213-$ 1220 (1991)

3）浅田稔, 谷内田正彦, 辻三郎：“運動物体の検出と追跡”, 信学 論, J62-D, 6, pp. 395-402 (1979)

4）野中利成, 木村茂, 小沢慎治：“適応型フレーム積分を用いた 移動物体抽出”, 信学論, J76-D-II, 1, pp. 84-91 (1993)

5）川端敦, 谷藤真也, 諸岡泰男: “移動物体の抽出技術”, 情処学 論, 28, 4, pp. 395-402 (1987)

6）黄秉元，高羽禎雄：“ITV 画像による人の流れの実時間計 測”, 信学論, J66-D, 8, pp. 917-924 (1983)

7）依田晴夫, 本池順, 江尻正員, 弓仲武雄：“実時間画像処理を 用いた待客数検出方式”，信学論，J69-D, 11，pp. 1679-1686 (1986)

8）石橋聡, 小林幸雄, 岸野文郎： “背景参照画像と両眼視差を用 いた任意背景中の人物像抽出”,テレビ誌, 45, 10, pp. 1270-

* 画像中の右足と左足をつなぐ線分の中央の点について, 地平面 での值を求め, これを真值とした. 
$1276(1991)$

9）平井宏, 三宅康雄, 堤喜代司，弓場芳治：“2 眼視による歩行 者の影の消去に関する一提案”, テレビ誌, 47, 3, pp. 392-394 (1993)

10）山本正信，ロベルト チポラ：“ステレオ動画像解析の一手 法”, 信学論, J72-D-II, 6, pp. 855-865 (1989)

11）山田友紀乃, 野中利成, 小沢慎治：“動画像を用いた人数の計 数の一手法”, 信学春季全大, D-633（1991）

\section{〈付 録〉画像変換式の導出}

付·図 1 に示すように，X- $Y$ 面が地平面に一致す る座標系 $X-Y-Z$ を絶対座標系とし，カメラのレン ズ中心が原点となるカメラ座標系 $x-y-z$ を考える. カメラ座標系 $x-y-z$ は絶対座標系 $X-Y-Z$ を平行移 動ののち回転したものに等しい. $X, Y, Z$ に一致し て $x, y, z$ をとるものとし, 座標系の原点を $(a, b, c)$ に移動して， $Z$ 軸の回りに $\alpha$ だけ回転したのち，X 軸の回りに $\beta$ だけ回転し，さらに $Y$ 軸の回りに $\gamma$ だ け回転したものをカメラ座標系とする。また，付·図 2 に示すように, カメラ座標系の原点から焦点距離 $f$ の位置にあって, $y$ 軸 (光軸) と垂直な平面を画像平面 とし，この平面上に座標系 $H-V$ をとる。

まず, $Z=0$ (つまり地平面上) での $(X, Y)$ と画像 平面での $(H, V)$ の関係を求める。 $(x, y, z)$ は, $(X$, $Y, Z)$ により

$$
\begin{aligned}
\left(\begin{array}{l}
x \\
y \\
z
\end{array}\right)= & \left(\begin{array}{ccc}
\cos \gamma & 0 & \sin \gamma \\
0 & 1 & 0 \\
-\sin \gamma & 0 & \cos \gamma
\end{array}\right)\left(\begin{array}{ccc}
1 & 0 & 0 \\
0 & \cos \beta & -\sin \beta \\
0 & \sin \beta & \cos \beta
\end{array}\right) \\
& \times\left(\begin{array}{ccc}
\cos \alpha & -\sin \alpha & 0 \\
\sin \alpha & \cos \alpha & 0 \\
0 & 0 & 1
\end{array}\right)\left(\begin{array}{l}
X-a \\
Y-b \\
Z-c
\end{array}\right) \text { (付・1) }
\end{aligned}
$$

と表される。ここで, $(a, b, c)$ は, $X-Y-Z$ 座標系で のカメラの位置であり, 絶対座標系の原点 $\mathrm{O}$ とカメ ラの距離を $r$ とすると

$$
\left\{\begin{array}{l}
a=r \cos \beta \sin \alpha \\
b=-r \cos \beta \cos \alpha \\
c=r \sin \beta
\end{array}\right.
$$

である.また $H, V$ は, カメラの焦点距離を $f$ とす ると, $x, y, z$ により

$$
H=f \frac{x}{y}, \quad V=f \frac{z}{y}
$$

と表される。（付・1）～(付・3) 式より，観測領域の 1 点 $(X, Y, Z)$ の画像での座標 $(H, V)$ は

$$
\begin{gathered}
H=f \frac{a_{1} X+b_{1} Y+c_{1} Z-\left(a_{1} a+b_{1} b+c_{1} c\right)}{a_{2} X+b_{2} Y+c_{2} Z-\left(a_{2} a+b_{2} b+c_{2} c\right)} \\
\text { （付 } \\
V=f \frac{a_{3} X+b_{3} Y+c_{3} Z-\left(a_{3} a+b_{3} b+c_{3} c\right)}{a_{2} X+b_{2} Y+c_{2} Z-\left(a_{2} a+b_{2} b+c_{2} c\right)}
\end{gathered}
$$

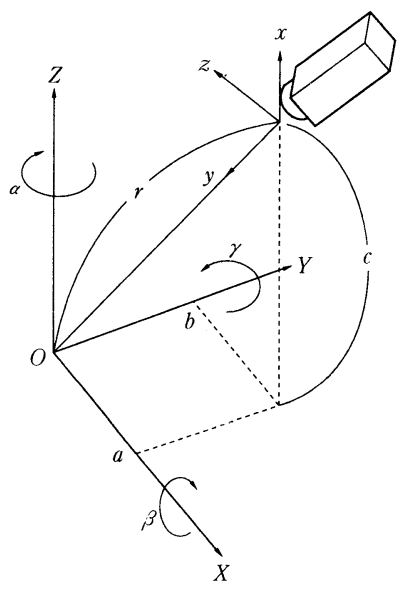

付・図 1 座標系の設定 Coordinate systems.

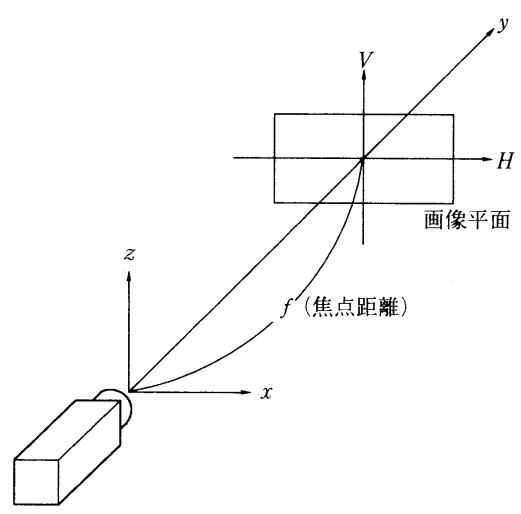

付·図 2 カメラの画像平面 Image plane of camera.

ただし

$$
\left\{\begin{array}{l}
a_{1}=\cos \alpha \cos \gamma+\sin \alpha \sin \beta \sin \gamma \\
a_{2}=\sin \alpha \cos \beta \\
a_{3}=-\cos \alpha \sin \gamma+\sin \alpha \sin \beta \cos \gamma \\
b_{1}=-\sin \alpha \cos \gamma+\cos \alpha \sin \beta \sin \gamma \\
b_{2}=\cos \alpha \cos \beta \\
b_{3}=\sin \alpha \sin \gamma+\cos \alpha \sin \beta \cos \gamma \\
c_{1}=\cos \beta \\
c_{2}=-\sin \beta \\
c_{3}=\cos \beta \cos \gamma
\end{array}\right.
$$

により求められる。 この式で $Z=0$ とすると， $(X$, $Y)$ と $(H, V)$ は 1 対 1 に対応する.したがって, $X$, $Y$ は, $H, V$ がわかると

$$
X=\frac{V\left(b_{2} d_{1}-b_{1} d_{2}\right)+H\left(b_{3} d_{2}-b_{2} d_{3}\right)+f\left(b_{1} d_{3}-b_{3} d_{1}\right)}{V\left(a_{2} b_{1}-a_{1} b_{2}\right)+H\left(a_{3} b_{2}-a_{2} b_{3}\right)+f\left(a_{1} b_{3}-a_{3} b_{1}\right)}
$$

(付・6) 


$$
Y=\frac{V\left(d_{2} a_{1}-d_{1} a_{2}\right)+H\left(d_{3} a_{2}-d_{2} a_{3}\right)+f\left(d_{1} a_{3}-d_{3} a_{1}\right)}{V\left(a_{2} b_{1}-a_{1} b_{2}\right)+H\left(a_{3} b_{2}-a_{2} b_{3}\right)+f\left(a_{1} b_{3}-a_{3} b_{1}\right)}
$$

(付 • 7)

ただし

$$
\left\{\begin{array}{l}
d_{1}=-\left(a_{1} a+b_{1} b+c_{1} c\right) \\
d_{2}=-\left(a_{2} a+b_{2} b+c_{2} c\right) \\
d_{3}=-\left(a_{3} a+b_{3} b+c_{3} c\right)
\end{array}\right.
$$

により求められる.

左カメラ画像における座標値 $H_{L}, V_{L}$ について, (付・6)，（付・7）式より $X$ 座標および $Y$ 座標の值を 求め, これを $X_{L}, Y_{L}$ とする。この $X_{L}, Y_{L}$ の值を右 カメラ画像についての(付・4), (付・5)式に代入する と, $H_{L}, V_{L}$ の新しい座標值 $H_{L}^{\prime}, V_{L}^{\prime}$

$$
\begin{aligned}
H_{L}^{\prime} & =F_{H R}\left(X_{L}, Y_{L}, 0\right) \\
V_{L}^{\prime} & =F_{V R}\left(X_{L}, Y_{L}, 0\right)
\end{aligned}
$$

が求められる.ここで, 右カメラ画像における座標值 $H_{R}, V_{R}$ を求める変換式を $F_{H R}(X, Y, Z), F_{V R}(X, Y$, $Z)$ と表している. $Z=0$ の面上の点に関しては， $\left(H_{L}^{\prime}\right.$, $\left.V_{L}^{\prime}\right)$ と $\left(H_{R}, V_{R}\right)$ が等しくなるが, $Z=0$ 以外の面上の 点に関しては等しくならない.

以上の式は画像変換の基本的な考方方を示してい る. 同次座標表現*を利用すれば，カメラの焦点距離 や配置（距離, 角度）などの值を求める必要がなくな る. 左カメラの画像平面上の 1 点 $\left(H_{L}, f_{L}, V_{L}\right)$ が同次 座標で $\left(M_{x L}, M_{y L}, M_{z L}, W_{L}\right)$ と表されるものとする. 右カメラの位置は左カメラを平行移動し, さらに回転 することにより得られるから, 平行移動と回転ののち の画像平面での同次座標 $\left(M_{x L}^{\prime}, M_{y L}^{\prime}, M_{z L}^{\prime}, W_{L}^{\prime}\right)$ は

$$
\left(\begin{array}{c}
M_{x L}^{\prime} \\
M_{y L}^{\prime} \\
M_{z L}^{\prime} \\
W_{L}^{\prime}
\end{array}\right)=\left(\begin{array}{llll}
e_{11} & e_{12} & e_{13} & e_{14} \\
e_{21} & e_{22} & e_{23} & e_{24} \\
e_{31} & e_{32} & e_{33} & e_{34} \\
e_{41} & e_{42} & e_{43} & e_{44}
\end{array}\right)\left(\begin{array}{c}
M_{x L} \\
M_{y L} \\
M_{z L} \\
W_{L}
\end{array}\right)
$$

と表される。また，左右のカメラの焦点距離が異なる と画像の拡大あるいは縮小が生じるが, これも上記の $4 \times 4$ の行列で表せる．同次座標から画像平面の座標 値は

$$
H_{L}^{\prime}=\frac{M_{x L}^{\prime}}{W_{L}^{\prime}}, \quad V_{L}^{\prime}=\frac{M_{z L}^{\prime}}{W_{L}^{\prime}}
$$

により求められ

\footnotetext{
* 例えば，D. H. パラード， C. M. ブラウン（福村晃夫他訳）：“コ ンピュータ・ビジョン”, A 1.1, A 1.7, 日本コンピュータ協会 (1987)
}

$$
\begin{aligned}
& H_{L}^{\prime}=\frac{e_{11} H_{L}+e_{12} f_{L}+e_{13} V_{L}+e_{14}}{e_{41} H_{L}+e_{42} f_{L}+e_{43} V_{L}+e_{44}} \quad \text { (付・11) } \\
& V_{L}^{\prime}=\frac{e_{31} H_{L}+e_{32} f_{L}+e_{33} V_{L}+e_{34}}{e_{41} H_{L}+e_{42} f_{L}+e_{43} V_{L}+e_{44}} \quad \text { (付・12) }
\end{aligned}
$$

となる.ここで, 左カメラの画像平面の座標 $\left(H_{L}\right.$, $\left.V_{L}\right)$, 焦点距離 $f_{L}$ が

$$
\left.\begin{array}{l}
H_{L}=\frac{M_{x L}}{W_{L}} \\
f_{L}=\frac{M_{y L}}{W_{L}} \\
V_{L}=\frac{M_{z L}}{W_{L}}
\end{array}\right\}
$$

と表されることを用いている，さらに，(付・11）， (付・12) 式の右辺の分母, 分子を定数 $e_{42} f_{L}+e_{44}$ で割 ると

$$
\begin{aligned}
& H_{L}^{\prime}=\frac{e_{11}^{\prime} H_{L}+e_{13}^{\prime} V_{L}+e_{14}^{\prime}}{e_{41}^{\prime} H_{L}+e_{43}^{\prime} V_{L}+1} \\
& V_{L}^{\prime}=\frac{e_{31}^{\prime} H_{L}+e_{33}^{\prime} V_{L}+e_{34}^{\prime}}{e_{41}^{\prime} H_{L}+e_{43}^{\prime} V_{L}+1}
\end{aligned}
$$

と表される. 画像変換において未知のパラメー夕は $e_{11}^{\prime}, e_{13}^{\prime}, e_{14}^{\prime}, e_{41}^{\prime}, e_{43}^{\prime}, e_{31}^{\prime}, e_{33}^{\prime}, e_{34}^{\prime}$ の 8 個である. 地平面 上の 4 点を定めて, 左右画像でそれらの座標値 $\left(H_{L}^{\prime}\right.$ と $H_{R}, V_{L}^{\prime}$ と $\left.V_{R}\right)$ が一致するように連立方程式を解くこ とにより,これらのパラメータの值が求められる.

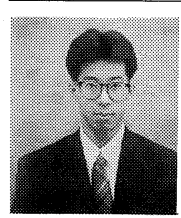

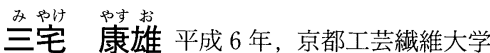
大学院工芸科学研究科博士前期課程修了. 現 在, 村田機械(株) に勤務. 在学中, 画像処理 による歩行者追跡の研究に従事.

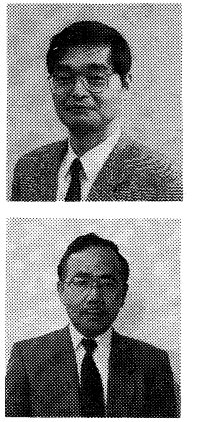

堤 喜点司 昭和 48 年, 京都工芸緎維大 学大学院工芸学研究科修士課程修了. 52 年, 京都工芸瀻維大学工芸学部電子工学科助手, 平成 2 年, 電子情報工学科助教授となり, 現 在に至る. 光導波路・光信号処理および画像 処理の研究に従事. 工学博士. 正会員.

平空䆖昭和 38 年, 大阪大学大学院 工学研究科修士課程修了. 41 年, 大阪大学 工学部通信工学科助手, 48 年, 京都工芸䋐 維大学工学部助教授となり, 現在に至る。デ イジタル信号処理・音声合成・画像処理・光 信号処理等の研究经従事. 工学博士. 正会 員.

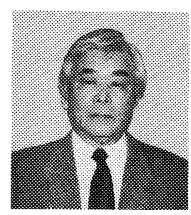

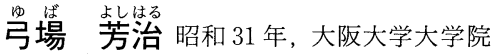
工学研究科修士課程修了. 大阪音響 (株), 大 阪大学・産業科学研究所, 基礎工学部勤務の のち, 京都工芸瀻維大学工芸学部助教授, 教 授を経て, 平成 5 年, 岡山県立大学教授とな り現在侄る。ミリ波伝送, 画像処理の研究 に従事. 工学博士. 正会員. 